Review Article

\title{
Immunodiagnosis in Jembrana Disease: A Review
}

\author{
${ }^{1,2}$ Asmarani Kusumawati, ${ }^{3}$ Tenri Ashari Wanahari, ${ }^{2,4}$ Widya Asmara, \\ ${ }^{1}$ Surya Agus Prihatno, ${ }^{3}$ Basofi Ashari Mappakaya and ${ }^{5}$ Bambang Hariono \\ ${ }^{I}$ Departement of Reproduction, Faculty of Veterinary Medicine, \\ Gadjah Mada University, Jalan Fauna No.2, Yogyakarta, 55281 Indonesia \\ ${ }^{2}$ Centre of Biotechnology Study, Gadjah Mada University, Jalan Teknika Utara, Yogyakarta, 55281 Indonesia \\ ${ }^{3}$ Faculty of Medicine, Sebelas Maret University, Jalan Ir. Sutami 36 A, Surakarta, 57126 Indonesia \\ ${ }^{4}$ Departement of Microbiology, Faculty of Veterinary Medicine, \\ Gadjah Mada University, Jalan Fauna No.2, Yogyakarta, 55281 Indonesia \\ ${ }^{5}$ Departement of Clinical Pathology, Faculty of Veterinary Medicine, \\ Gadjah Mada University, Jalan Fauna No.2, Yogyakarta, 55281 Indonesia
}

Article history

Received: 30-10-2014

Revised: $16-08-2015$

Accepted: 17-08-2015

Corresponding Author:

Asmarani Kusumawati

Department of Reproduction,

Faculty of Veterinary Medicine,

Gadjah Mada University, Jalan

Fauna no.2, Yogyakarta, 55281

Indonesia

Tel: +6281328867709

$+6274560863$

Fax: +6274560863

Email: kartapati_2008@yahoo.com

\begin{abstract}
Jembrana disease is a bovine disease that affects Bali cattle (Bos javanicus). The causal agent is named Jembrana Disease Virus (JDV), a lentivirus member. The disease development of Jembrana disease in Bali cattle is unique for a lentivirus infection as it is related with severe clinical syndrome in an acute period. In experimentally JDV-infected Bali cattle, the death rate was about $21 \%$ and occurred within only 1 to 2 weeks postinfection. Indeed, the mortality of more than 60000 cattles in a year was observed during the first outbreak and the disease is now endemic throughout parts of Indonesia. Early diagnosis constitutes a preventive method of further disease outbreaks. The Jembrana disease can be diagnosed by the clinical symptoms but more reliable diagnostic tools are available, based on either antigen (immunodiagnosis) or viral genome (molecular diagnosis). In this review, we summarize about immunodiagnostic tools of Jembrana disease which has been developed so far.
\end{abstract}

Keywords: Immunodiagnosis, Bovine Disease, Humoral Immune Response, Immunologic Test, Immunoassay

\section{Introduction}

Jembrana disease is a bovine disease that affects Bali cattle (Bos javanicus). It was first identified in the Jembrana district of Bali island (Indonesia). Thus the causal agent is named Jembrana Disease Virus (JDV), a lentivirus member of the family Retroviridae (Kusumawati et al., 2014a). The disease is now endemic through-out parts of Indonesia, particularly in Java, Sumatra, Kalimantan (Hartaningsih et al., 1993) and also in Australia (Chadwick et al., 1998). The disease development of Jembrana disease in Bali cattle is unique for a lentivirus infection as it is related with severe symptoms in an acute period (Dharma et al., 1991). The mortality of more than 60000 cattles in a year was observed during the first outbreak (Hartaningsih et al., 1993). In experimentally JDV-infected Bali cattle, the death rate was about 21\% (Soesanto et al., 1990; Soeharsono et al., 1990). This finding was supported with evidence acquired in several epidemiological studies (Soeharsono et al., 1995a; 1995b; Chadwick et al., 1998). In lethal infection, mortality was occurred within only 1 to 2 weeks after infection and was correlated to multiorgan failure (Wilcox et al., 1995; Wilcox, 1997). The economical aspect of Jembrana disease in Bali cattle in Indonesia is also important to be considered since these cattle have been widely spread throughtout Indonesia. Bali cattle comprise about $27 \%$ of the total cattle population of Indonesia-the highest contribution to beef production in Indonesia (Desport and Lewis, 2010).

Virus-borne diseases are among the most difficult to overcome as drugs are usually expensive or not available in most cases. Early diagnosis constitutes a preventive method of further disease outbreaks. Bioassay provides a method for titration of infectious virus but it is timeconsuming and expensive. Techniques that do not require the use of animals for assay are needed for easy and efficient detections and routine health controls of 
JDV infections in cattle industry. Techniques that enable easy virus quantification are also needed for further studies on the kinetics of virus replication during the acute phase of the disease process and for understanding the persistence of virus in recovered animals. The Jembrana disease can be diagnosed by the clinical symptoms but more reliable diagnostic tools are available, based on either antigen (immunodiagnosis) or viral genome (molecular diagnosis). In this review, we summarize about immunodiagnostic tools of Jembrana disease which has been developed so far.

\section{Clinical Symptoms}

JDV infection is characterized by acute, severe disease syndrome in Bali cattle (Chadwick et al., 1998). Briefly, the main clinical symptoms in Bali cattle include elevated body rectal temperature, lethargy, anorexia, diarrhoea with blood in feces, pallor of the mucus membrane, swollen of the superficial lymph nodes during the febrile phase, high titer of infectious virus in blood and secreted fluids (milk, saliva) (Soeharsono et al., 1990; Soesanto et al., 1990). In experimental infections, study showed that JDV had the capability to infect other type of cattles, including the most prevalent farmed cattle, such as Ongole cattle (Bos indicus) and Friesian cattle (Bos taurus), buffaloes (Bubalus bubalis), sheep, goats and pigs (Soeharsono et al., 1990; Wilcox et al., 1995). However, it is hard to establish the clinical diagnosis especially in other cattle species and pigs infected with JDV as it is only develop a mild febrile response (Wilcox et al., 1995; Soeharsono et al., 1990). The clinical symptoms are not always precise and may be difficult to establish at the initial time course of infection.

\section{Antibody Response to JDV Infection}

Lethal infection often occurs in JDV-infected cattle due to secondary infections (Dharma et al., 1991), resulting from temporary immunosuppression characteristic to Jembrana disease (Wareing et al., 1999). The temporary immunosuppression occurring during the acute phase was demonstrated by a decline of Immunoglobulin-G (IgG) containing cells in the lymphoid organs proven by immunohistochemistry method (Dharma et al., 1994; Desport et al., 2009a). This finding was supported with studies by EnzymeLinked Immunosorbent Assay (ELISA) and Agar Gel Immunodiffusion (AGID) which showed a slowed antibody response (Desport and Lewis, 2010). JDVspecific antibodies were remained undetected until 11 weeks post-infection in most infected cattle. This antibody response was maximal at 23-33 weeks postinfection and was still detectable at 59 weeks postinfection (Hartaningsih et al., 1994).

\section{Immunodiagnostic Tool: Viral Detection Based on Antibody Response}

\section{Use of Whole Viral Particles}

The first developed serodiagnosis used plasma-derived virus, purified by sucrose gradient, to detect antibody response in infected Bali cattle (Hartaningsih et al., 1993; 1994). It is based on Enzyme-Linked Immunosorbent Assay (ELISA) and Agar Gel Immunodiffusion (AGID). This diagnostic method allowed to distinguish clinicallypositive cattle for Jembrana disease, which gave a positive response, from cattle originated from Jembrana disease-free areas in Bali which were negatively responding (Hartaningsih et al., 1994). According to this study, AGID was less sensitive than ELISA. The method has also been used to detect JDV infections in other parts of Indonesia, including Java (East provinces) and Sumatra (Lampung and West Sumatra) (Hartaningsih et al., 1993). The drawback of the method is its usefulness for detecting JDV infection during the initial stage of disease development and during the acute phase because JDV infections induce a temporary immunosuppression in cattle, resulting in delayed antibody response (Dharma et al., 1994; Hartaningsih et al., 1994; Wareing et al., 1999).

\section{Optimization by Recombinant Antigens}

Optimizing the serodiagnostic tool was further carried out by using recombinant JDV antigens, i.e., the Capsid (CA) and Transmembrane (TM) subunits of the respective gag and env ORF (Burkala et al., 1998). Recombinant proteins were produced by a prokaryotic expression in E. coli as soluble proteins fused to Glutathione-S-Transferase (GST) (Burkala et al., 1998). Using antisera from JDV-naturally infected Bali cattle (Bos javanicus) or Bovine Immunodeficiency Virus (BIV)-infected taurine cattle (Bos taurus) in Western blot analysis (Burkala et al., 1998) and ELISA (Barboni et al., 2001), it appeared that the recombinant JDV CA and TM reacted well with antisera from animals infected by JDV or BIV. This finding is indeed not surprising as the two bovine lentiviruses are genomically and antigenically very closely related (Chadwick et al., 1995). Antibodies produced by infected cattle recognize antigens originating from both lentiviruses. Sequence comparison of the expressed regions showed $63 \%$ identity for $\mathrm{TM}$ and $66 \%$ for $\mathrm{CA}$ proteins of JDV and BIV. This identity is indicative of shared common immunogenic epitopes (Burkala et al., 1998; Kertayadnya et al., 1993). The lentivirus CA proteins contain a conserved epitope (Grund et al., 1994) and the antigenic cross-reactivity can, to a certain extent, be attributed to this epitope. The TM cross-reactive epitope was not identified but is possibly the principal TM immunodominant domain. 


\section{Immunodiagnostic Tool: Detection of Viral Antigens}

\section{Improvement of the Diagnosis Efficacy by Antigen Capture ELISA}

Immunodiagnostic tools are convenient and relatively easy to perform. However their sensitivity still needs to be increased, firstly for detecting low amounts of viral particles and also for their possible quantification. Improvement was achieved by antigen capture ELISA. The method is based on the recognition of JDV-p26 (capsid protein), prepared from plasma, by a specific monoclonal antibody coated to the well of ELISA tray. The captured antigen was then identified by rabbit antiJDV-p26 antiserum (Stewart et al., 2005). Though not allowing to distinguish JDV- from BIV-infections, the antigen capture ELISA is reliable for quantification of JDV-p26 over a linear range of 10 to $200 \mathrm{ng} \mathrm{mL}^{-1}$ of plasma, allowing to correlate the antigen concentration with the number of viral RNA genome copies. Using this method, it has been shown that a peak of p26 concentration is attained during the acute phase and indeed at this stage the titer of infectious units is the highest as attested by analysis by real-time RT-PCR (Stewart et al., 2005). During the acute phase, in plasma, the p26 concentration, the RNA copy number (Stewart et al., 2005) and the infectious units (Soeharsono et al., 1990) are respectively $3.5 \mu \mathrm{g}$ $\mathrm{mL}^{-1}, 10^{12}$ copies $/ \mathrm{ml}$ and $0.5 \times 10^{9} \mathrm{ID}_{50} / \mathrm{mL}$. It proved so that antigen capture ELISA is not only highly sensitive but importantly it also enables to quantify the viral load in plasma and consequently to determine the stages of the disease development.

\section{Differentiating Antigen}

A study suggested a possibility distinguising antibody to BIV and JDV (Barboni et al., 2001). However attempts to locate JDV-specific antigenic determinants confirming this finding were unsuccessful. Various recombinant proteins have been tested but they were unable to differentiate antisera of JDV-infected from BIV-induced antisera (Desport et al., 2005). Attempts to identify distinguishing epitopes are only made feasible by using monoclonal antibody approach. Indeed, a monoclonal antibody raised against BIV gag protein - a capsid protein, was found to only recognize BIV protein and not the JDV counterpart in Western blotting (Zheng et al., 2001). The differentiating BIV gag epitope appeared to be the unique epitope that is not shared by JDV (Lu et al., 2002). Further identification by chemical cleavage analysis, recombinant overlapping peptides and synthetic peptide showed that the specific epitope is 26 amino acids in length and composed of $6 \mathrm{C}$-terminal amino acids of the matrix protein $\left(\mathrm{p} 16^{\mathrm{MA}}\right)$ followed by $20 \mathrm{~N}$-terminal amino acid residues of the $\mathrm{p} 2 \mathrm{~L}$ peptide ( $\mathrm{Lu}$ et al., 2002). This epitope is absent in JDV because the intragenic $\mathrm{p} 2 \mathrm{~L}$ is missing in JDV (Lu et al., 2002). The BIV-specific epitope is of great interest in confirming or disproving JDV infection by defect. Indeed, JDV infections will be characterized by a positive response in e.g., capsidbased detection but by a negative response to BIVspecific epitope monoclonal antibody (Zheng et al., 2001; Lu et al., 2002).

\section{Future Direction}

JDV antigen detection using ELISA was found to be more sensitive than Western blot (Barboni et al., 2001; Lewis et al., 2009). In addition, latest achievement method in immunodiagnosis is gain by JDVp26 capture ELISA that facilitated monitoring and detection of circulating viral antigen during the acute phase of the disease. An understanding of the use of a tyramide-based signal amplification substrate which allow the detection of little titer of HIV-1 p24 antigen may provide important clue to increase the sensitivity of the current method JDVp26 capture ELISA. Substantial progress can also be made by continuing research to improve JDVp26 antigen ELISA which may be affected by JDVp26 monoclonal antibodies (Stewart et al., 2005). Furthermore, antibody-based diagnostic methods do not enable to distinguish JDV- from BIV-infection as the two bovine lentiviruses are antigenically very closely related (Fultz, 1991; Soeharsono et al., 1990). Distinguishing BIV-infection was only made feasible by using a BIV-specific monoclonal antibody that only recognizes the unique BIV gag epitope, which is not shared by JDV (Lu et al., 2002).

JDV infection induces a delayed humoral response (Dharma et al., 1994; Hartaningsih et al., 1994). The majority infected animals cultivate possible amount of antibodies to be detected only 6 weeks or more after recovery from the acute phase of the disease (Desport et al., 2009b; Desport and Lewis, 2010; Tenaya et al., 2012). This ensue severe disease as the limitation of immunodiagnosis that cannot be used in acute stage of the disease. Moreover, immunodiagnosis are comprised by cross-reactive epitopes in the CA protein of JDV and BIV (Burkala et al., 1998; Kertayadnya et al., 1993). During the acute phase, high titer of infectious JDV viral particles is found in plasma (Kusumawati et al., 2014b). Viruses are also abundantly present in secreted fluids, namely milk and saliva (Soeharsono et al., 1995b). This make viral antigen identification by molecular method is ideal detection tool in order to detect viral infection as early as possible during the course of the disease. However, molecular detection method is not always applicable as it requires a high technical skill and 
expensive equipments.Several viral genome amplification tools have been developed for the identification of JDV, such as in situ dot-blot hybridization (Chadwick et al., 1998), polymerase chain reaction (Stewart et al., 2005) and loop-mediated isothermal amplification which was the more recently developed and was the more sensitive (Kusumawati et al., 2015). Nevertheless, finding from a comparative study (immunological vs molecular detection methods) recommended that a combination of molecular detection and immunodiagnosis method is used for routine control of Jembrana disease in Bali cattle (Lewis et al., 2009).

\section{Conclusion}

Immunodiagnosis is more convenient for use in routine health controls than bioassays or anapathological analyses even if these latter are suitable techniques for post mortem diagnosis. The methodologies rely on either the humoral immune response of JDV-infected cattle or the presence of JDV antigens. However, given that JDVspecific antibodies are not produced in most infected cattle untill 11 weeks post infection (Dharma et al., 1994; Hartaningsih et al., 1994; Wareing et al., 1999), immunodiagnosis based on host humoral response can not be used in early stages of the disease. Maximal production of antibodies only occurs at 23-33 weeks post-infection even if antibodies are still detectable at 59 weeks post-infection (Hartaningsih et al., 1994). Detection of JDV infection is so preferably based on the presence of viral antigens in order to detect viral infection as early as possible during the course of the disease to prevent further disease outbreaks. Optimizing the serodiagnosis is achieved by antigen capture ELISA which also allows the quantification of JDV viral particles although the method is unable to distinguish JDV- from BIV-infection (Stewart et al., 2005). Differentiating BIV infections is feasibly attained by the use of a specific monoclonal antibody, only recognizing BIV capside protein epitope that is absent in JDV (Zheng et al., 2001; Lu et al., 2002). Though relatively insensitive, ELISA provides an economical and feasible method for monitoring the virus in the absence of more sensitive methods (Barboni et al., 2001; Lewis et al., 2009).

\section{Acknowledgment}

We acknowledge to Professor Sri Hartati, DVM, $\mathrm{MSc}, \mathrm{PhD}$ for provided general support and aid.

\section{Funding Information}

This work partly funded by a grant from Directorate General Higher Education (DIKTI), Ministry of Education and Culture of Indonesia.

\section{Author's Contribution}

Asmarani Kusumawati: Participated in all aquisition of literatures, reviewed the literatures, coordinated and contributed to the writing of the manuscript.

Tenri Ashari Wanahari: Participated in all aquisition of literatures, reviewed the literatures and contributed to the writing of the manuscript.

Widya Asmara: Reviewed the literatures and provided the technical guidance in literature review study.

Surya Agus Prihatno: Reviewed the literatures and provided the technical guidance in literature review study.

Basofi Ashari Mappakaya: Contributed to the writing of the manuscript.

Bambang Hariono: Provided the technical guidance in literature review study.

\section{Ethics}

This study was approved by Research Ethics Commitee, Faculty of Veterinary Medicine, Gadjah Mada University, Indonesia.

\section{References}

Barboni, P., I. Thompson, J. Brownlie, N. Hartaningsih and M.E. Collins, 2001. Evidence for the presence of two bovine lentiviruses in the cattle population of Bali. Vet. Microbiol., 80: 313-27. PMID: 11348768

Burkala, E.J., I. Narayani, N. Hartaningsih, G. Kertayadnya and D.I. Berryman et al., 1998. Recombinant Jembrana disease virus proteins as antigens for the detection of antibody to bovine lentiviruses. J. Virol. Methods., 74: 39-46. PMID: 9763127

Chadwick, B.J., R.J. Coelen, G.E. Wilcox, L.M. Sammels and G. Kertayadnya, 1995. Nucleotide sequence analysis of Jembrana disease virus: A bovine lentivirus associated with an acute disease syndrome. J. Gen. Virol., 76: 1637-50. PMID: 9049370

Chadwick, B.J., M. Desport, J. Brownlie, G.E. Wilcox and D.M. Dharma, 1998. Detection of Jembrana disease virus in spleen, lymph nodes, bone marrow and other tissues by in situ hybridization of paraffin-embedded sections. J. Gen. Virol., 79: 101-6. PMID: 9460930

Dharma, D.M., A. Budiantono, R.S. Campbell and P.W. Ladds, 1991. Studies on experimental Jembrana disease in Bali cattle. III. Pathology. J. Comp. Pathol., 105: 397-414. PMID: 1663137

Dharma, D.M., P.W. Ladds, G.E. Wilcox and R.S. Campbell, 1994. Immunopathology of experimental Jembrana disease in Bali cattle. Vet. Immunol. Immunopathol., 44: 31-44. PMID: 7725629 
Desport, M., M.E. Stewart, C.A. Sheridan, W.G. Ditcham and S. Setiyaningsih et al., 2005. Recombinant Jembrana disease virus gag proteins identify several different antigenic domains but do not facilitate serological differentiation of JDV and nonpathogenic bovine lentiviruses. J. Virol. Methods, 124: 135-42. PMID: 15664061

Desport, M., W.G.F. Ditcham, J.R. Lewis, T.J. McNab and M.E. Stewart et al., 2009a. Analysis of Jembrana disease virus replication dynamics in vivo reveals strain variation and atypical responses to infection. Virology, 386: 310-6. PMID: 19230948

Desport, M., I.W.M. Tenaya, A. McLachlan, T.J. McNab and J. Rachmat et al., 2009b. In vivo infection of IgG-containing cells by Jembrana disease virus during acute infection. Virology, 393: 221-7. DOI: 10.1016/j.virol.2009.07.027

Desport, M. and J. Lewis, 2010. Jembrana disease virus: Host responses, viral dynamics and disease control. Curr. HIV. Res., 8: 53-65. PMID: 20210780

Fultz, P.N., 1991. Replication of an acutely lethal simian immunodeficiency virus activates and induces proliferation of lymphocytes. J. Virol., 65: 4902-9. PMID: 1870205

Grund, C.H., E.R. Lechman, C.J. Issel, R.C. Montelaro and K.E. Rushlow, 1994. Lentivirus cross-reactive determinants present in the capsid protein of equine infectious anaemia virus. J. Gen. Virol., 75: 657-62. PMID: 7510329

Hartaningsih, N., G.E. Wilcox, D.M. Dharma and M. Soetrisno, 1993. Distribution of Jembrana disease in cattle in Indonesia. Vet. Microbiol., 38: 23-9. PMID: 8128600

Hartaningsih, N., G.E. Wilcox, G. Kertayadnya and M. Astawa, 1994. Antibody response to Jembrana disease virus in Bali cattle. Vet. Microbiol., 39: 15-23. PMID: 8203120

Kertayadnya, G., G.E. Wilcox, S. Soeharsono, N. Hartaningsih and R.J. Coelen et al., 1993. Characteristics of a retrovirus associated with Jembrana disease in Bali cattle. J. Gen. Virol., 74: 1765-78. PMID: 7690840

Kusumawati, A., T.A. Wanahari, R.F. Putri, B.A. Mappakaya and I.D. Tampubolon, 2014a. The structure and function of Jembrana disease virus genome. J. Inf. Mol. Biol. Sci., 2: 26-9.

DOI: $10.14737 /$ jimb.2307-5465/2.2.26.29

Kusumawati, A., T.A. Wanahari, R.F. Putri, T. Untari and T. Hartati et al., 2014b. Clinical and pathological perspectives of Jembrana disease virus infection: A review. Biosci. Biotech. Res. Asia., 11: 1221-5. DOI: $10.13005 / \mathrm{bbra} / 1509$
Kusumawati, A., T.A. Wanahari, I.D. Tampubolon and B.A. Mappakaya, 2015. The comparison of RTLAMP, RT-PCR and dot-blot hybridization for detection of jembrana disease virus. Am. J. Biochem. Biotechnol., 11: 114-8.

DOI: 10.3844/ajbbsp.2015.114.118

Lewis, J., T. McNab, M. Tenaya, N. Hartaningsih and G. Wilcox et al., 2009. Comparison of immunoassay and real-time PCR methods for the detection of Jembrana disease virus infection in Bali cattle. J. Virol. Methods., 159: 81-6. PMID: 19442849

Lu, M., L. Zheng, K. Mitchell, S. Kapil and C. Wood et al., 2002. Unique epitope of bovine immunodeficiency virus gag protein spans the cleavage site between p16(MA) and p2L. Clin. Diagn. Lab. Immunol., 9: 1277-1281. PMID: 12414761

Soeharsono, S., N. Hartaningsih, M. Soetrisno, G. Kertayadnya and G.E. Wilcox, 1990. Studies of experimental Jembrana disease in Bali cattle. I. Transmission and persistence of the infectious agent in ruminants and pigs and resistance of recovered cattle to re-infection. J. Comp. Pathol., 103: 49-59. PMID: 2394846

Soeharsono, S., G.E. Wilcox, D.M. Dharma, N. Hartaningsih and G. Kertayadnya et al., 1995a. Species differences in the reaction of cattle to Jembrana disease virus infection. J. Comp. Pathol., 112: 391-402. PMID: 7593761

Soeharsono, S., G.E. Wilcox, A.A. Putra, N. Hartaningsih and K. Sulistyana et al., 1995b. The transmission of Jembrana disease, a lentivirus disease of Bos javanicus cattle. Epidemiol. Infect., 115: 367-374. PMID: 7589275

Soesanto, M., S. Soeharsono, A. Budiantono, K. Sulistyana and M. Tenaya et al., 1990. Studies on experimental Jembrana disease in Bali cattle. II. Clinical signs and haematological changes. J. Comp. Pathol., 103: 61-71. PMID: 2394847

Stewart, M., M. Desport, N. Hartaningsih and G. Wilcox, 2005. TaqMan real-time reverse transcription-PCR and JDVp26 antigen capture enzyme-linked immunosorbent assay to quantify Jembrana disease virus load during the acute phase of in vivo infection. J. Clin. Microbiol., 43: 5574-80. PMID: 16272489

Tenaya, I.W.M., K. Heel, P.A. Stumbles and G.E. Wilcox, 2012. Flow cytometric analysis of lymphocyte subset kinetics in Bali cattle experimentally infected with Jembrana disease virus. Vet. Immunol. Immunopathol., 149: 167-176. DOI: $10.1016 /$ j.vetimm.2012.06.013 
Wareing, S., N. Hartaningsih, G.E. Wilcox and W.J. Penhale, 1999. Evidence for immunosuppression associated with Jembrana disease virus infection of cattle. Vet. Microbiol., 16: 179-85.

PMID: 10501175

Wilcox, G.E., B.J. Chadwick and G. Kertayadnya, 1995. Recent advances in the understanding of Jembrana disease. Vet. Microbiol., 46: 249-255.

DOI: $10.1016 / 0378-1135(95) 00089-S$
Wilcox, G.E., 1997. Jembrana disease. Aus. Vet. J., 75: 492-3. DOI: $10.1111 /$ j.1751-0813.1997.tb14379.x

Zheng, L., S. Zhang, C. Wood, S. Kapil and G.E. Wilcox et al., 2001. Differentiation of two bovine lentiviruses by a monoclonal antibody on the basis of epitope specificity. Clin. Diagn. Lab. Immunol., 8: 283-7. PMID: 11238209 